\title{
Raquel Carvalho, The Remedy of Ineffectiveness: Reform Perspectives (Sankcja uznania umowy za nieskuteczną: perspektywy zmian), „European Procurement \& Public Private Partnership Law Review" 2017, vol. 12, iss. 4, s. 374-382, DOI: 10.21552/epppl/2017/4/4.
}

Przestrzenią badawcza, w której porusza się autorka artykułu, jest sfera środków ochrony prawnej w prawie zamówień publicznych. W warstwie normatywnej współtworzą ją regulacje Dyrektywy 2007/66/UE (i dyrektyw wcześniejszych) oraz przepisy krajowych aktów normatywnych, którymi nastąiło ich wdrożenie (autorka uwzględnia przede wszystkim regulacje prawa portugalskiego). R. Carvalho prowadzi swoje rozważania również, opierając się na treści Sprawozdania Komisji dla Parlamentu Europejskiego i Rady w sprawie efektywności Dyrektywy 89/66/ EWG i dyrektywy 92/13/EWG, zmienionych Dyrektywą 2007/66/WE, dotyczących procedur odwoławczych $\mathrm{w}$ dziedzinie zamówień publicznych.

Jednym z przewidzianych w ramach środków odwoławczych mechanizmów jest sankcja uznania umowy za nieskuteczną, która stanowi główny przedmiot rozważań autorki. W artykule ukazano regulacje prawne, w tym prawa portugalskiego, dotyczące wskazanego mechanizmu, z uwzględnieniem ich ewolucji oraz skutków, jakie wynikały z wprowadzanych zmian. Pobocznie autorka zwraca uwagę na inne istotne naukowo oraz praktycznie kwestie.

W szczególności warto odnotować rozważania dotyczące prawnej relacji pomiędzy umowami w sprawie zamówień publicznych a umowami administracyjnymi oraz przyjętymi przez prawodawcę portugalskiego $\mathrm{w}$ tym zakresie regulacjami. W Portugalii większość zamówień publicznych stanowi jednocześnie umowy administracyjne. $W$ konsekwencji znajdują do nich zastosowanie zarówno regulacje dotyczące umów w sprawie zamówień publicznych, jak i umów administracyjnych. Powyższe wpływa także na aspekty instytucjonalne - organy właściwe do rozpoznawania spraw związanych z materią zamówień publicznych. Podmiotem właściwym do rozpoznawania środków ochrony prawnej, niezależnie od statusu prawnego instytucji zamawiającej, jest sąd administracyjny. Autorka wskazuje na odmienność tego rozwiązania od istniejących w innych państwach członkowskich UE, w tym w Belgii, w której jurysdykcja sądu (administracyjnego albo cywilnego) determinowana jest charakterem statusu prawnego instytucji zamawiającej. Wśród elementów prawnoporównawczych zaprezentowanych w artykule warto również zwrócić uwagę na porównanie długości okresów standstill ustanowionych w poszczególnych państwach członkowskich UE, a także rozwiązań w zakresie momentu, 
od którego następuje unieważnienie umowy w sprawie zamówienia publicznego (ex nunc albo ex tunc).

Elementem proceduralnym, który stanowi przedmiot rozważań autorki, jest m.in. krąg podmiotów uprawnionych do kwestionowania przedkontraktowych czynności podjętych przez instytucje zamawiające. Warto odnotować, na co zwraca uwagę R. Carvalho, że regulacje prawa portugalskiego nie ograniczają grona podmiotów uprawnionych do wnoszenia odwołania wyłącznie do podmiotów, którym przysługuje prawo do ubiegania się o udzielenie zamówienia (wykonawców). Pozostają w nim także podmioty reprezentujące interes publiczny.

Autorka zwraca szczególną uwagę na instytucję automatycznego zawieszenia możliwości udzielenia zamówienia w sytuacji wniesienia odwołania. Jest ona w prawie portugalskim uzupełniona o doniosłe praktyczne rozwiązanie, które modyfikuje wymieniony zakaz zawarcia umowy w sytuacji, w której kontrakt został już zawarty. Regulacje prawa portugalskiego przewidują wstrzymanie realizacji kontraktu na skutek wniesienia odwołania, jeżeli umowa została już zawarta.

W formie konkluzji autorka podaje w wątpliwość stanowisko o braku konieczności wprowadzania zmian w dyrektywie odwoławczej. R. Carvalho stoi na stanowisku, zgodnie z którym zmiany o charakterze ewolucyjnym są niezbędne m.in. ze względu na konieczność dostosowania obowiązujących regulacji do rozwiązań wdrożonych dyrektywami 2014/24/UE oraz 2014/25/UE - regulującymi proces udzielania zamówień. Przykładowo, autorka wskazuje na celowość rozważenia, w jakim zakresie procedury odwoławcze winny znajdować zastosowanie do materii modyfikacji umów w sprawie zamówień publicznych. 